\title{
Erratum to: Isolation and characterization of polymorphic microsatellite markers for genetic analysis of chub mackerel (Scomber japonicus)
}

Hyung Kee Cha $\cdot$ Hye Suck An · Jung Hwa Choi •

Sukyung Kang • Jung Youn Park • Kyung Kil Kim

Published online: 13 February 2010

(C) Springer Science+Business Media B.V. 2010

Erratum to: Conservation Genet Resour

DOI 10.1007/s12686-009-9123-7

The contribution number appearing in the Acknowledgments section should read: RP-2009-BT-22.

The online version of the original article can be found under doi:10.1007/s12686-009-9123-7.

H. K. Cha · J. H. Choi · S. Kang

Fisheries Resources Research Team, National Fisheries Research

and Development Institute, Busan 619-902, Korea

H. S. An $(\bowtie) \cdot$ J. Y. Park · K. K. Kim

Biotechnology Research Division, National Fisheries Research

and Development Institute, Busan 619-902, Korea

e-mail: hsan@nfrdi.go.kr 